\title{
ASSESSMENT OF SURFACE WATER DYNAMICS USING MULTIPLE WATER INDICES AROUND ADAMA WOREDA, ETHIOPIA
}

\author{
Manikandan Sathianarayanan 1,* \\ ${ }^{1}$ Department of Civil Engineering, National Taiwan University, Taiwan - d06521026@ntu.edu.tw
}

Commission V, SS: Natural Resources Management

KEY WORDS: NDWI, WRI, MNDWI, Surface water

\begin{abstract}
:
Rapid change of Adama wereda during the last three decades has posed a serious threat to the existence of ecological systems, specifically water bodies which play a crucial part in supporting life. Role of Satellite images in Remote Sensing could be more important in investigation, monitoring dynamically and planning of natural surface water resources. Landsat-5(TM) \& Landsat 8 (OLI) has high spatial, temporal and multispectral resolution and therefore provides consistent and perfect data to detect changes in surface changes of water bodies. In this paper, a study was conducted to detect the changes in water body extent during the period of 1984,2000 \&2017 using various water indices such as namely Water Ratio Index (WRI), Normalized Difference Water Index (NDWI), Modified Normalized Difference Water Index (MNDWI), supervised classification and wetness component of K-T transformation and the results are Presented. NDWI has been adopted for this study as compared with other indices through ground survey. The results showed an intense decreasing trend in the lakes of chelekleka ,kiroftu ,lake 1 and lake 3 of surface area in the period 1984-2017, especially between 2000 and 2017 when the lake lost about $1.309 \mathrm{~km} 2$ (one third) of its surface area compared to the year 2000, which is equivalent to $76 \%, 18 \%, 0.03 \%$ and $96 \%$. Interestingly koka lake has shown very erratic changes in its area coverage by losing almost 3.5 sq.km between 1984 and 2000 and then climbing back up by 14.8 sq.km in 2017. Percentage of increment was observed that $10.6 \%$ as compared with previous year.
\end{abstract}

\section{INTRODUCTION}

Assessment and monitoring the changes in environment using remote sensing technology is extensively used in various applications, such as land use/cover change (Salmon et al.,2013; Demir et al.,2013), disaster monitoring (Volpi et al.,2013; Brisco et al.,2013), forest and vegetation change (Kaliraj et al., 2012; Markogianni et al.,2013), urban sprawl (Bagan et al.,2012; Raja et al.,2013), and hydrology (Dronova et al.,2011; Zhu et al.,2011). surface water will play an important role in human survival and social development Ridd and Liu (1998). It is most needful for humans, food crops, and ecosystems (Lu et al.,2011). Collecting information about the spatial distribution of open surface water is most important in various scientific disciplines, such as the assessment of present and future water resources, river dynamics, wetland inventory, climate models watershed analysis, surface water survey and management, agriculture suitability, flood mapping, and environment monitoring (Desmet and Govers,1996; Zhou and Wu,2008; Du et al.,2012; Sun et al.,2012). Recently developed remote sensing satellites with different spatial, spectral and temporal resolution provide an abundant data that become primary sources and being used for detecting and extracting surface water and its changes in recent decades (Xu,2006; Zhou et al.,2011; Tang et al.,2013; Li et al.,2013; McFeeters,2013). Images from Landsat series was one of the most widely used remote sensing data that adopted for water body detection as well as changes over the periods (Moradi et al.,2017). Landsat series satellite has different sensor such as multispectral scanner (MSS) for Landsat -1 to Landsat -3, Thematic mapper (TM)for Landsat -4 and Landsat-5 and Enhanced Thematic mapper plus(ETM+) have been used for many environmental applications specifically for water body dynamics studies (moradi et al.,2017, Mcfeeters,1996; Xu,2006). Latest era on Landsat series has begun with Operational Land Imager(OLI) on board Landsat 8 has 12-bit pixel instead of 8-bit pixel of ETM+ that gives higher quality and better signal to noise ratio than ETM+ (Irons et al.,2012).

Several algorithm has been adopted for change detection studies on water body especially on Landsat data that categorized in to four main groups:1- classification and pattern recognition methods it includes supervised (Tulbure et al.,2013) and unsupervised methods (Ko et al.,2015).2-spectral un-mixing (sethre et al.,2005).3-single band threshold (Klein et al.,2014) and 4-spectral water index (Ji et al.,2009). Errors are more common when single band methods chosen to extract water features along with different cover types because of defined threshold values are needed to extract water features( $\mathrm{Du}$ et al.,2012).index based methods are more accurate than classification methods it does not require any basic knowledge (Li et al.,2013).Multi band methods comprises two or more different reflective bands for improved surface water extraction (Du et al.,2012).For instance, Normalized difference water index(NDWI) has developed for extracting water feature from satellite imagery.

In the past decade there are Different indices has lined up for extracting water surface.one of the popular water index is normalized difference water index(NDWI)(Mcfeeters,1996). Modified normalized difference water index has been developed to overcome the problem of water pixel mixed with buildup features $(\mathrm{Xu}, 2006)$. Automated water extraction index (AWEI) was introduced to get better result which Landsat image has shadow and dark surface. Water Ratio Index (WRI) is another widely used water index by Shen, $\mathrm{L}$ and C. Li (2010). This study

\footnotetext{
* Corresponding author
} 
has, therefore, implemented NDWI among others to extract and quantify the water surface area changes of ADAMA wereda and its surrounding. In doing so, Landsat images of 1984 (TM) 2000(TM) \& 2017(OLI) has been used. The main objective of this project is to detect the surface water change detection patterns (1984-2017) of Landsat multispectral images using different water indices in Adama woreda and its surrounding.

\section{STUDY AREA}

The study area, Adama wereda have 100145.61-hectare area coverage. It comprises Adama city, Wonji sugar factory and town, Koka Lake, and other rural Kebeles. Adama wereda is located in Oromia region, east Shoa zone and it bounds a geographic coordinates ranging from $39^{\circ} 27^{\prime} \mathrm{E}$ to $39^{\circ} 30^{\prime} \mathrm{E}$ and $8^{\circ} 21^{\prime} \mathrm{N}$ and $8^{\circ} 46^{\prime} 30^{\prime \prime}$ and the altitude of Adama Woreda ranges from 1500 to 2300 meters above Mean Sea Level (MSL). The population is moderately dense and annual rainfall is $500-800$ $\mathrm{mm}$. It is bounded by beset wereda in the east, Lome wereda in the North West, Duga bora in south west, Dodo tana sire wereda in south and Shenkora and minjar in north. The varied topography which includes hills, plains and undulating landscapes with lakes and the rift valley escarpment. The major types of vegetation are bush scrub, grasslands. Only few places are covered by little forest. location of lakes in study area has given below.

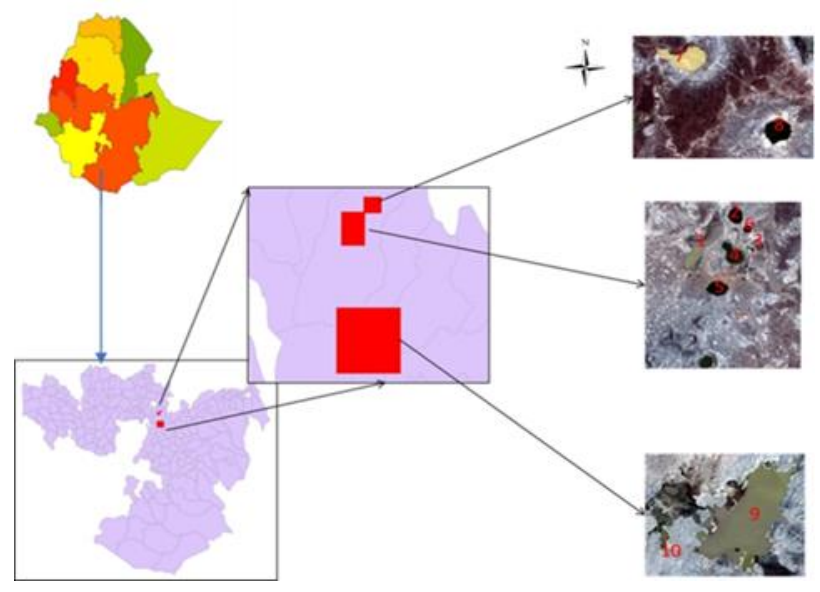

Figure 1. Location of Lakes in AdamaWoreda

\section{METHODOLOGY}

The procedure performed in this project will derived the change in Adama wereda and it's surrounding over a different period of time, the change detection in Adama wereda is carried out in the three satellite images over different period of time $(1984,2000$ \&2017). figure 2 below explains about entire flow of work.

\subsection{Water Surface Extraction}

In order to detect the changes in surface water area of Adama woreda and its surrounding in the period 1984-2015, To analyze the performance of different satellite derived indices including Normalized Difference Water Index (NDWI), Modified Normalized Difference Water Index (MNDWI), Modified, Water Ratio Index (WRI), KT Transform and Supervised classification has been examined for extraction of surface water from individual temporal Landsat data

\begin{tabular}{|c|c|c|c|}
\hline S.No & Lake name & Latitude & Longitude \\
\hline 1 & Chelekleka & $8^{\circ} 45^{\prime} 39.64 " \mathrm{~N}$ & $38^{\circ} 58^{\prime} 8.58^{\prime \prime E}$ \\
\hline 2 & BishoftuGuda & $8^{\circ} 47^{\prime} 15.13 " \mathrm{~N}$ & $38^{\circ} 59^{\prime} 35.03 " \mathrm{E}$ \\
\hline 3 & Kiroftu & $8^{\circ} 46^{\prime} 45.63 " \mathrm{~N}$ & $39^{\circ} 0^{\prime} 1.69^{\prime \prime} \mathrm{E}$ \\
\hline 4 & Hora & $8^{\circ} 45^{\prime} 44.59^{\prime \prime} \mathrm{N}$ & $38^{\circ} 59^{\prime} 30.70^{\prime \prime} \mathrm{E}$ \\
\hline 5 & Bishoftu & $8^{\circ} 44^{\prime} 36.03^{\prime \prime N}$ & $38^{\circ} 59^{\prime} 2.62^{\prime \prime} \mathrm{E}$ \\
\hline 6 & Lake 1 & $8^{\circ} 46^{\prime} 45.81^{\prime \prime N}$ & $39^{\circ} 1 ' 12.46 " \mathrm{E}$ \\
\hline 7 & K'oftu & $8^{\circ} 49^{\prime} 50.15^{\prime \prime N}$ & $39^{\circ} 2^{\prime} 55.37^{\prime \prime} \mathrm{E}$ \\
\hline 8 & Lake 2 & $8^{\circ} 48^{\prime} 12.13^{\prime \prime} \mathrm{N}$ & $39^{\circ} 4^{\prime} 59.15^{\prime \prime} \mathrm{E}$ \\
\hline 9 & Koka & $8^{\circ} 24^{\prime} 53.15^{\prime \prime} \mathrm{N}$ & $39^{\circ} 6^{\prime} 30.51 " \mathrm{E}$ \\
\hline 10 & Lake 3 & $8^{\circ} 21^{\prime} 37.51 " \mathrm{~N}$ & $38^{\circ} 57^{\prime} 16.34^{\prime \prime E}$ \\
\hline
\end{tabular}

Table 1. Location of lakes around Adama woreda and its surrounding

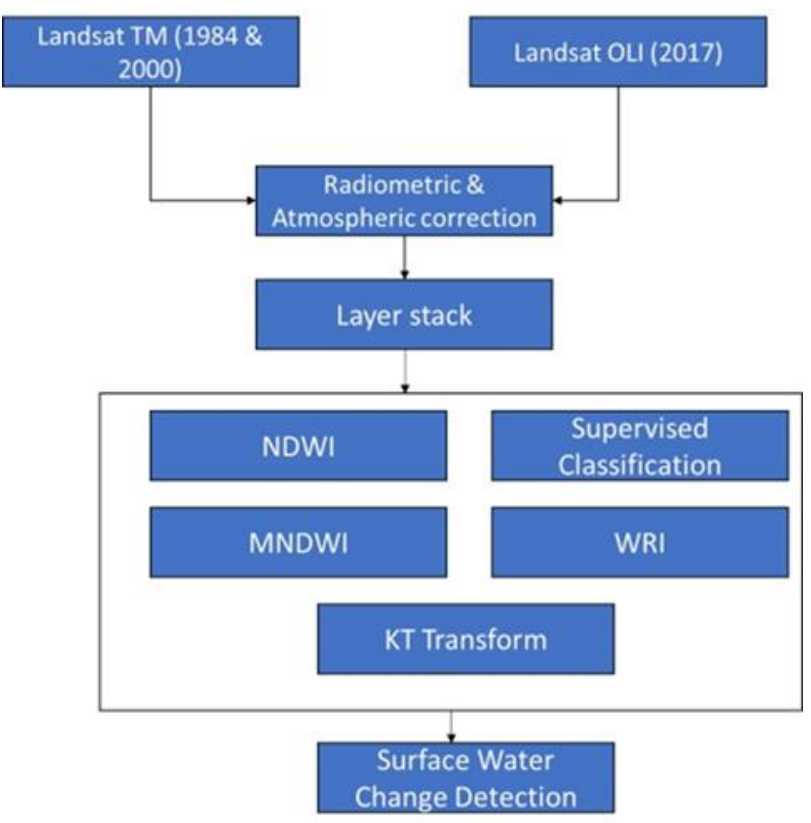

Figure 2. Methodology adopted for Study

NDWI, MNDWI, WRI, KT Transform and supervised classification were needed to calculate from Landsat 1984 TM,2000TM \& 2017OLI images to assess their performances for the extraction of surface water. Threshold value for land-water for each index has given manually to classify the image in to two categories, water and non-water. (Komeil et al.,2014). suitable threshold value has been identified by doing trial and error and comparison to reference map generated using visual interpretation. Near infrared (NIR) band is usually preferred for visual interpretation of water bodies. Because NIR is strongly absorbed by water and its reflected by vegetation and dry soil. 


\begin{tabular}{|c|c|c|}
\hline Index & Equation & Remark \\
\hline $\begin{array}{l}\text { Normalized } \\
\text { Difference in Water } \\
\text { Index }\end{array}$ & $\begin{array}{l}\text { NDWI }= \\
(\text { Green-NIR }) / \\
(\text { Green + NIR }) \\
\end{array}$ & $\begin{array}{l}\text { Water has } \\
\text { positive value. }\end{array}$ \\
\hline $\begin{array}{l}\text { Wetness component of } \\
\text { K-T transformation }\end{array}$ & $\begin{array}{l}0.1509 * \text { Blue }+.1 \\
793 * \text { Green }+ \\
0.3279 * \text { Red }+ \\
0.3406 * \text { NIR+ } \\
0.7112 * \text { MIR }+ \\
0.4572 * \text { SWIR }\end{array}$ & $\begin{array}{l}\text { Water has } \\
\text { positive value }\end{array}$ \\
\hline $\begin{array}{lr}\text { Modified } & \text { Normalized } \\
\text { Difference } & \text { Water } \\
\text { Index }\end{array}$ & $\begin{array}{l}\text { MNDWI= } \\
(\text { Green-MIR)/ } \\
(\text { Green + MIR) }\end{array}$ & $\begin{array}{l}\text { Water has } \\
\text { positive value }\end{array}$ \\
\hline Water Ratio Index & $\begin{array}{l}\text { WRI }= \\
(\text { Green + Red }) / \\
(\mathrm{NIR}+\mathrm{MIR})\end{array}$ & $\begin{array}{l}\text { Value of water } \\
\text { body is greater } \\
\text { than } 1\end{array}$ \\
\hline
\end{tabular}

Table 2. Satellite-derived indexes used for water features extraction in Landsat imagery

\subsection{Water Ratio Index (WRI)}

Since prevailing spectral reflectance of water in green (band-2) and red (Band3) bands as compared to Near Infra-red (Band 4) and Medium Infra-red (Band 5). Values of Water Ratio Index(WRI) shows that greater than 1 for water (Shen L and Li C,2010; Fang et al.,2011). where WRI is defined as

\section{$\mathrm{WRI}=\mathrm{Green}+\mathrm{Red} / \mathrm{NIR}+\mathrm{MIR}$}

Fig 3 shows a Convincing result for water has been noticed in the year of 2000 and 2017. But in 1984, Surface water falls under the value ranges less than 1 .

\subsection{Normalized Difference Water Index (NDWI)}

NDWI was introduced by McfeetersS.K. (1996) to extract surface water from Landsat images depends on strong absorption of water and strong reflection of vegetation in the portion of Near infra-red regions.

\section{NDWI=Green-NIR/ Green+NIR}

Index value ranges from -1 to +1 with water body has high values (very close to positive 1). Result proved that NDWI has ability to separate water body and vegetation but it has some sort of limitation on soil and built up area.

\subsection{Modified Normalized Difference Water Index (MNDWI)}

In order to overcome the limitations of NDWI on urban areas, $\mathrm{Xu}$ (2006) proposed new approach MNDWI which was found to be more efficient in distinguishing water and urban areas. MNDWI can be achieved with replacing infrared by shortwave Infrared wavelength of 1.57-1.65 micro meters.

\section{MNDWI=Green-MIR/GREEN+MIR}

Some of the results has been observed while computing Modified Normalized Difference water index are, 1) water has higher positive values than in NDWI as it absorbs more MIR than NIR.2). negative values indicate that built up land,3). still vegetation and soil will have negative values as soil reflects MIR more than NIR(Jensen,2004) and vegetation will reflect MIR
Figure 3. water ratio index of years 1984(a),2000(b)and 2017(c).

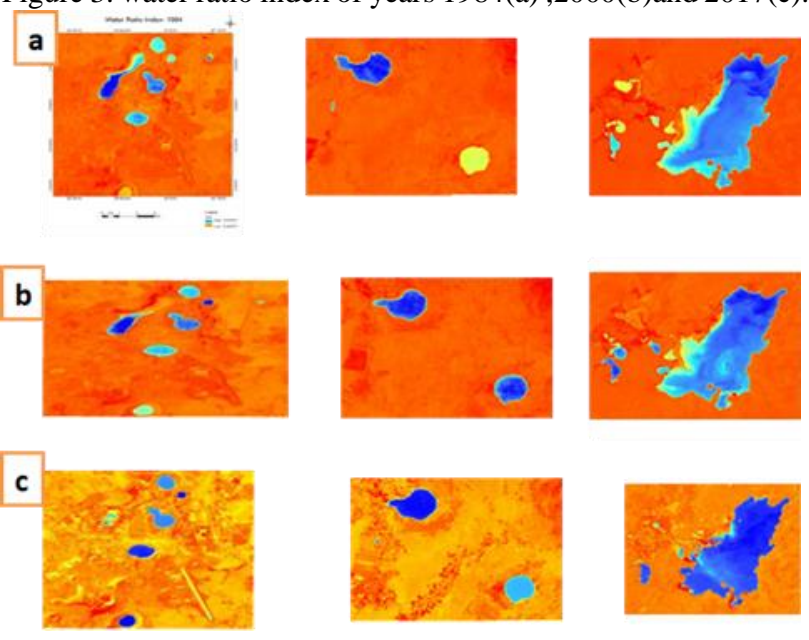

more than green.

Advantage of MNDWI is that more accurate in extraction of open surface water body as built up land, soil and vegetation all negative values and it was suppressed.
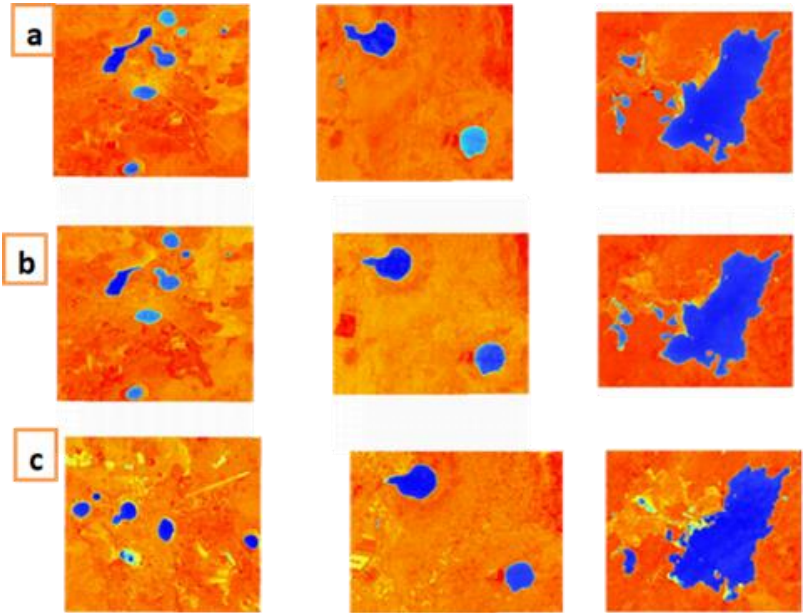

Figure 4. Modified Normalized difference in water indices of 1984(a), 2000(b)and 2017(c).

\subsection{Wetness component of K-T transformation}

Tasseled cap transformation, also called K-T transformation, it provides coordinate axis point to the direction has close by association with features through rotating coordinate space. Once rotation has performed, pointing direction of coordinate axis was closely related to process of plant growth and soil (Yanan et al., 2013). It helps to analyze and interpret the crop characteristics and good practical significance. KT transform was introduced by Kauth and Thomas (1996) to distinguish between three special features as brightness, greenness and yellowness for MSS data. Afterwards, Crist and Cicone(1984) utilized the tasseled cap transformation for Thematic mapper data. The weights are different and the third component is taken to represent soil wetness rather than yellowness as in Kauth and Thomas' original formulation. The wetness component of K-T transform can be utilized to extract water information wherein a weighted sum of bands of ETM+ is taken according to the following formula (Vivek et al.,2015): 
Wetness $=0.1509 *$ Blue $+0.1793 *$ Green $+0.3279 *$ Red $+0.3279 *$ Red+0.3406*NIR_0.7112*MIR_0.4572*MIR*0.4572*SWIR
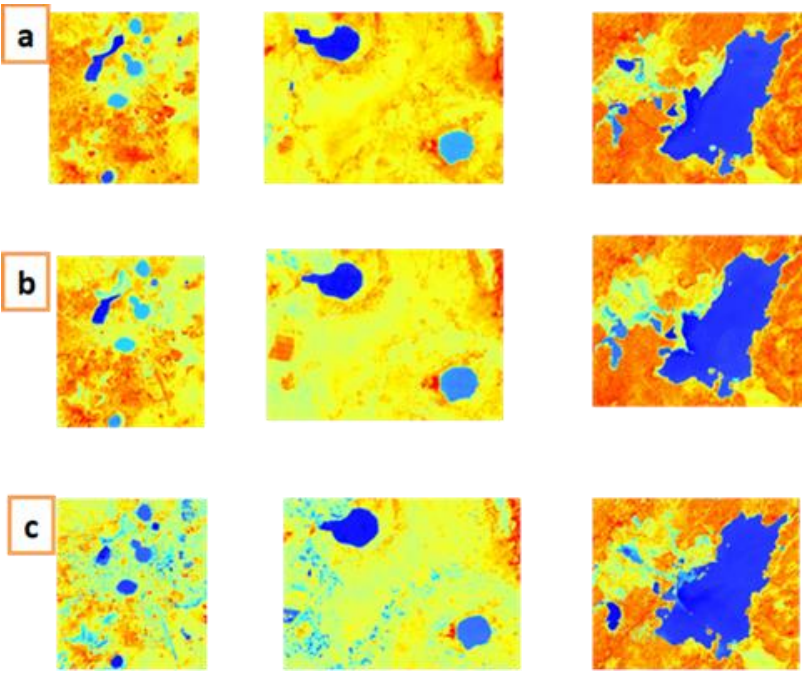

Figure 5. wetness KT Transform of 1984(a), 2000(b) and 2017(c)

\subsection{Supervised Classification}

Supervised classification is the process of grouping pixels using a known identity of specific sites (i.e., pixels already assigned to informational classes) to classify pixels of unknown identity (i.e., to assign unclassified pixels to one of the several informational classes (Cambell, 2002). Knowledge of study area, aerial photography, and experience with remotely sensed data etc. are required before undergoing training samples. The training samples were provided over the image for known and unambiguous representatives for each class namely Water body and non-water. Maximum likelihood supervised classification was utilized over the image.

\section{RESULT AND DISCUSSION}

\subsection{Surface water changes from 1984-2000}

Surface water area for each of the 10 lakes were calculated by using Normalized Difference Water Index (NDWI) for 1984\& 2000 (TM) and 2017 (OLI_TIRS). Figure 2 shows that Lakes Chelekleka, BishoftuGuda, Kiroftu, Lake 1, K'oftu,Lake2, and Koka has shown very little change in their shape \& spatial coverage for all years. Unlike lakes bishoftu, lake 2 and lake 3 has shown a very significant and discernible change in its surface area cover for each study year. The surface area change detection confirms that Lake BishoftuGuda, Kiroftu, Lake 1 and K'oftuhas shown little change in their surface area over the study years. Lake koka has seen its maximum surface area reduction of $3.51 \mathrm{sqkm}$ between 1984 and 2000. Surface water area increment was evident in 2000 with Hora, Bishoftu, Lake 2 and Lake 3 were $0.041 \mathrm{sqkm}, 0.0087 \mathrm{sqkm}, 0.280 \mathrm{sqkm}, 1.02 \mathrm{sqkm}$ respectively. The overall surface area changes for the study area between 1984 and 2000was -3.94sqkms (negative sign indicating a decreasing trend). +1.359 sq.km (positive sign indicates that increase in trend).

\subsection{Surface Water Changes from 2000-2017}

Surface water area for each of the 10 lakes were calculated by using Normalized Difference Water Index (NDWI) for 2000 and
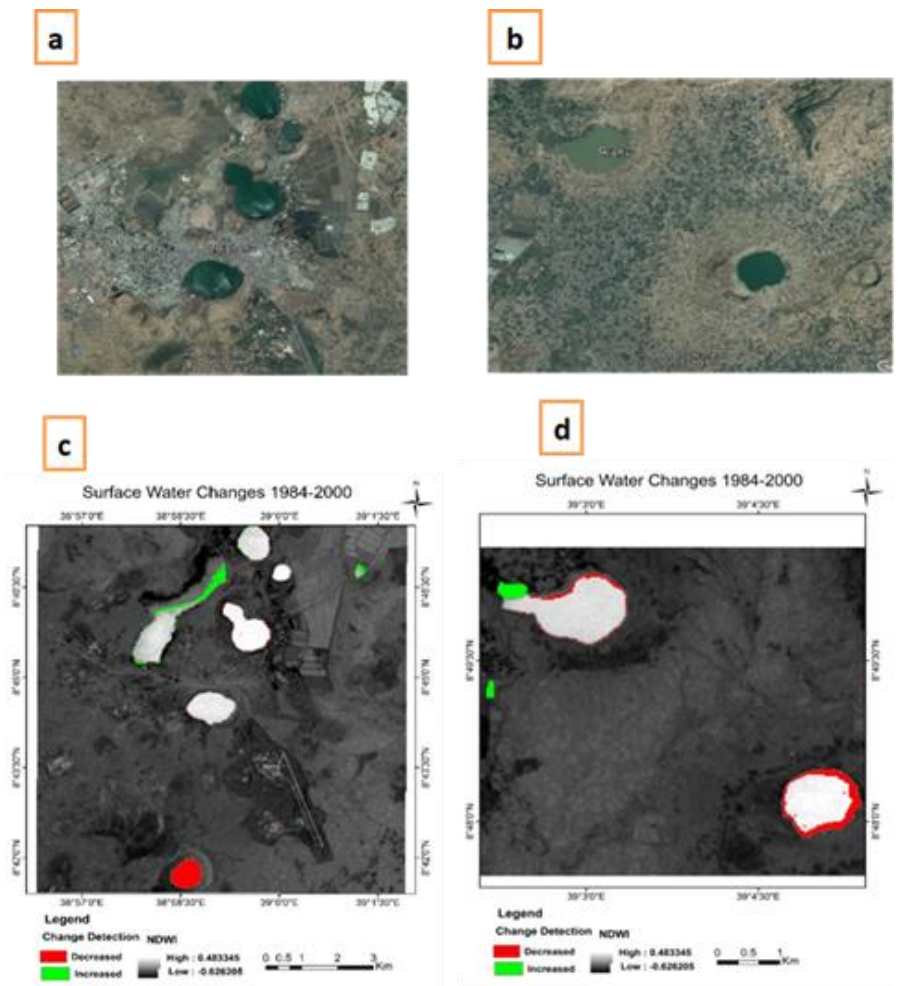

Figure $6, a \& b$ shows that current scenario of lake and $c \& d$ shows changes from 2000-2017
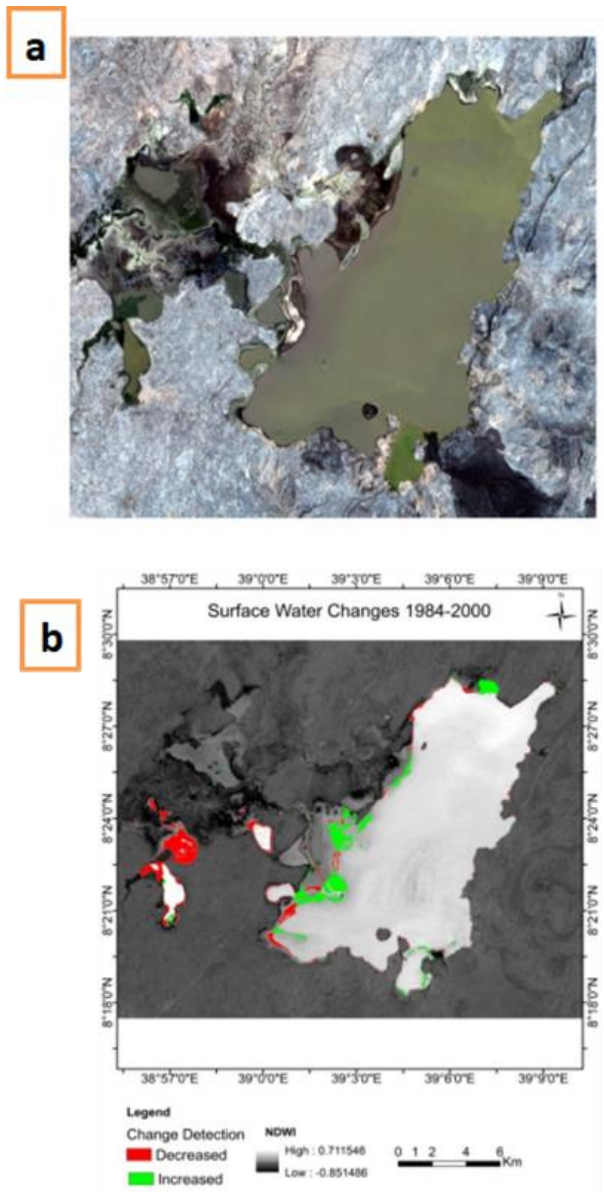

Figure 7, a \& b shows that current scenario of lake from Google map and changes 
2017 (OLI_TIRS). Figure shows that Lakes Kiroftu, Lake 1 and Lake 2has shown very little change in their shape \& spatial coverage for all years. Unlike lakes chelekleka and lake 3has shown a very significant and discernible change in its surface area cover for each study year. The surface area change detection confirms that Lake Bishoftu Guda Kiroftu, Hora, K'oftu, Koka has shown little change in their surface area over the study years. Lake koka has seen its maximum surface area increase of 14.88 sqkm between 2000 and 2017. apart from koka lake other lakes namely Bishoftu Guda Kiroftu, Hora, K'oftu has increased as compared with previous year in terms of area were $0.010 \mathrm{sqkm}, 0.0091 \mathrm{sq} \mathrm{km}, 0.020 \mathrm{sq} \mathrm{km}, 0.04$ sq.km. The overall surface area changes for the study area between 2000 and 2017 was $-4.98 \mathrm{sqkms}$ (negative sign indicating a decreasing trend). $+14.96401 \mathrm{sq} \mathrm{km}$ (positive sign indicates that increase in trend).

a

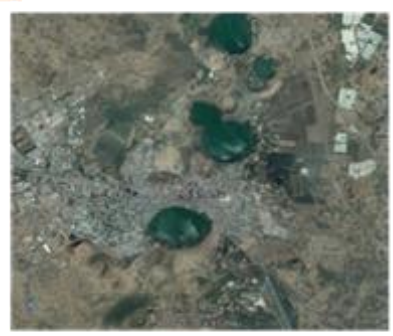

c

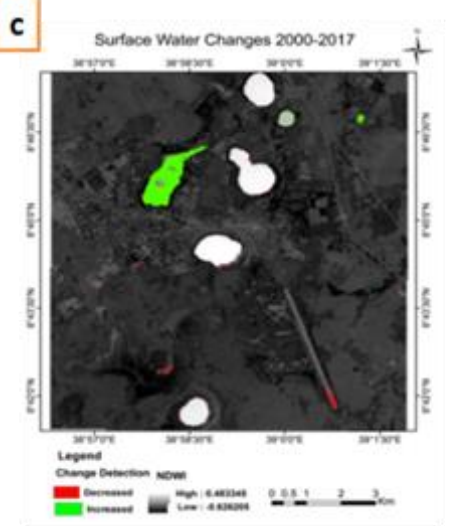

8 , a\& b shows that current scenario of lake and c\& d shows changes from 2000-2017

\begin{tabular}{|c|c|c|c|c|c|c|}
\hline \multicolumn{3}{|c|}{ chelekleka } & \multicolumn{2}{|c|}{ Bishoftu Guda } & \multicolumn{2}{|c|}{ Kiroftu } \\
\hline year & $\begin{array}{l}\text { Estimated } \\
\text { surface } \\
\text { area } \\
(\mathrm{sq} \mathrm{km})\end{array}$ & $\begin{array}{l}\text { surface } \\
\text { area } \\
\text { changes } \\
\text { from } \\
\text { previous } \\
\text { year }\end{array}$ & $\begin{array}{l}\text { Estimated } \\
\text { surface } \\
\text { area } \\
(\mathrm{sq} \mathrm{km})\end{array}$ & $\begin{array}{l}\text { surface } \\
\text { area } \\
\text { changes } \\
\text { from } \\
\text { previous } \\
\text { year }\end{array}$ & $\begin{array}{l}\text { Estimated } \\
\text { surface } \\
\text { area } \\
(\mathrm{sq} \mathrm{km})\end{array}$ & $\begin{array}{l}\text { surface } \\
\text { area } \\
\text { changes } \\
\text { from } \\
\text { previous } \\
\text { year }\end{array}$ \\
\hline 1984 & 1.611 & & 0.707 & & 0.200 & \\
\hline 2000 & 1.250 & -0.361 & 0.704 & -0.002 & 0.194 & -0.006 \\
\hline 2017 & 0.015 & -1.235 & 0.715 & 0.010 & 0.158 & -0.036 \\
\hline
\end{tabular}

Table 3. Surface water changes during the years 1984- 2017
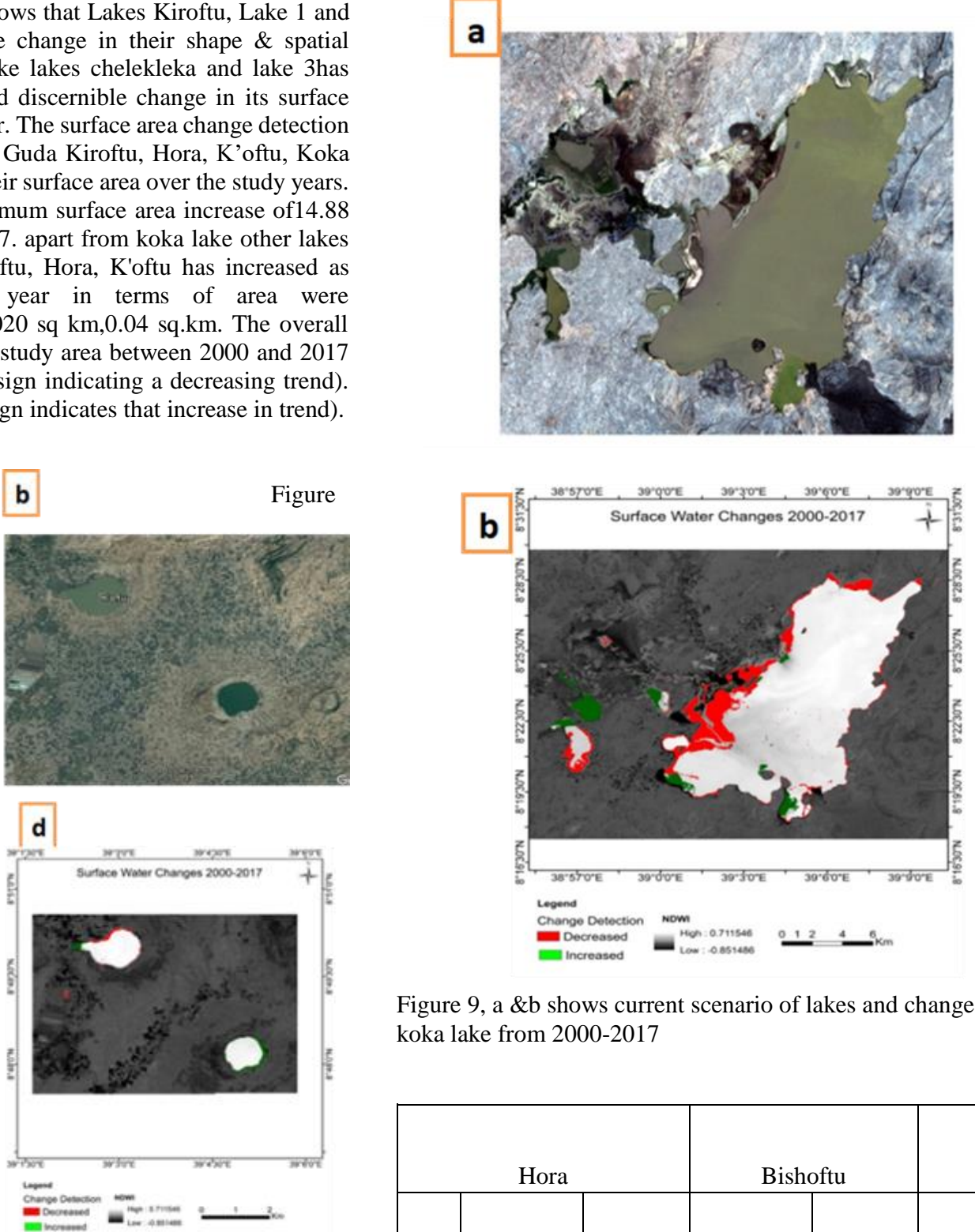

Figure 9 , a \&b shows current scenario of lakes and changes in koka lake from 2000-2017

\begin{tabular}{|c|c|c|c|c|c|c|}
\hline \multicolumn{3}{|c|}{ Hora } & \multicolumn{2}{|c|}{ Bishoftu } & \multicolumn{2}{|c|}{ No Name 1} \\
\hline year & $\begin{array}{l}\text { Estimated } \\
\text { surface area } \\
(\mathrm{sq}-\mathrm{km})\end{array}$ & $\begin{array}{l}\text { surface } \\
\text { area } \\
\text { changes } \\
\text { from } \\
\text { previous } \\
\text { year }\end{array}$ & $\begin{array}{l}\begin{array}{l}\text { Estimated } \\
\text { surface area } \\
(\mathrm{sq} \mathrm{km})\end{array} \\
\end{array}$ & \begin{tabular}{|l} 
surface \\
area \\
changes \\
from \\
previous \\
year
\end{tabular} & $\begin{array}{l}\text { Estimated } \\
\text { surface area } \\
(\mathrm{sq} \mathrm{km})\end{array}$ & $\begin{array}{l}\text { surface } \\
\text { area } \\
\text { changes } \\
\text { from } \\
\text { previous } \\
\text { year }\end{array}$ \\
\hline 1984 & 1.067 & & 0.933 & & 0.083 & \\
\hline 2000 & 1.109 & 0.042 & 0.942 & 0.009 & 0.038 & -0.046 \\
\hline 2017 & 1.118 & 0.009 & 0.963 & 0.021 & 0.000 & -0.038 \\
\hline
\end{tabular}

Table 4. Surface water changes during the years 1984- 2017 


\begin{tabular}{|c|c|c|c|c|c|c|c|c|}
\hline \multicolumn{3}{|c|}{ K'oftu } & \multicolumn{2}{|c|}{ No Name 2} & \multicolumn{2}{|l|}{ Koka } & \multicolumn{2}{|c|}{ No Name 3} \\
\hline year & \begin{tabular}{|l} 
Estimate \\
$\mathrm{d}$ \\
surface \\
area \\
$(\mathrm{sq} \mathrm{km})$
\end{tabular} & \begin{tabular}{|l|} 
surface \\
area \\
change \\
$\mathrm{s}$ \\
from \\
previou \\
s year \\
\end{tabular} & \begin{tabular}{|l} 
Estimate \\
d \\
surface \\
area \\
$($ sq km)
\end{tabular} & \begin{tabular}{|l} 
surface \\
area \\
change \\
$\mathrm{s}$ \\
from \\
previou \\
$\mathrm{s}$ year \\
\end{tabular} & \begin{tabular}{|l} 
Estimate \\
d \\
surface \\
area \\
(sq km) \\
\end{tabular} & \begin{tabular}{|l} 
surface \\
area \\
change \\
$\mathrm{s}$ \\
from \\
previou \\
$\mathrm{s}$ year \\
\end{tabular} & $\begin{array}{l}\text { Estimate } \\
\mathrm{d} \\
\text { surface } \\
\text { area } \\
(\mathrm{sq} \mathrm{km})\end{array}$ & \begin{tabular}{|l} 
surface \\
area \\
change \\
$\mathrm{s}$ \\
from \\
previou \\
s year \\
\end{tabular} \\
\hline $\begin{array}{l}198 \\
4\end{array}$ & 1.368 & & 0.785 & & 139.151 & & 2.572 & \\
\hline $\begin{array}{l}200 \\
0 \\
\end{array}$ & 1.357 & -0.010 & 1.065 & 0.281 & 135.636 & -3.516 & 3.601 & 1.028 \\
\hline $\begin{array}{l}201 \\
7 \\
\end{array}$ & 1.400 & 0.043 & 0.876 & -0.189 & 150.516 & 14.881 & 0.112 & -3.489 \\
\hline
\end{tabular}

Table 5. Surface water changes during the years 1984- 2017

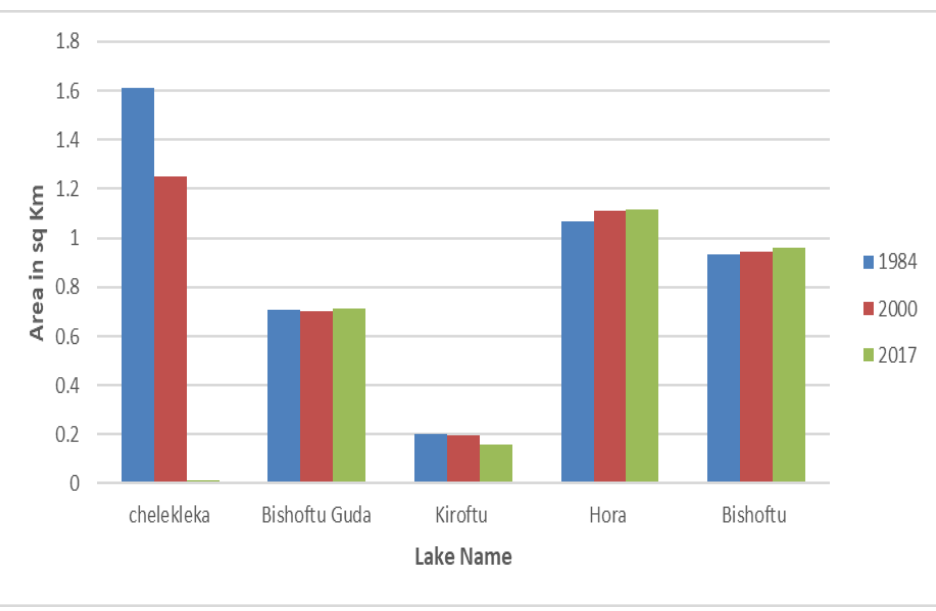

Figure 10. Area of surface water during 1984-2017

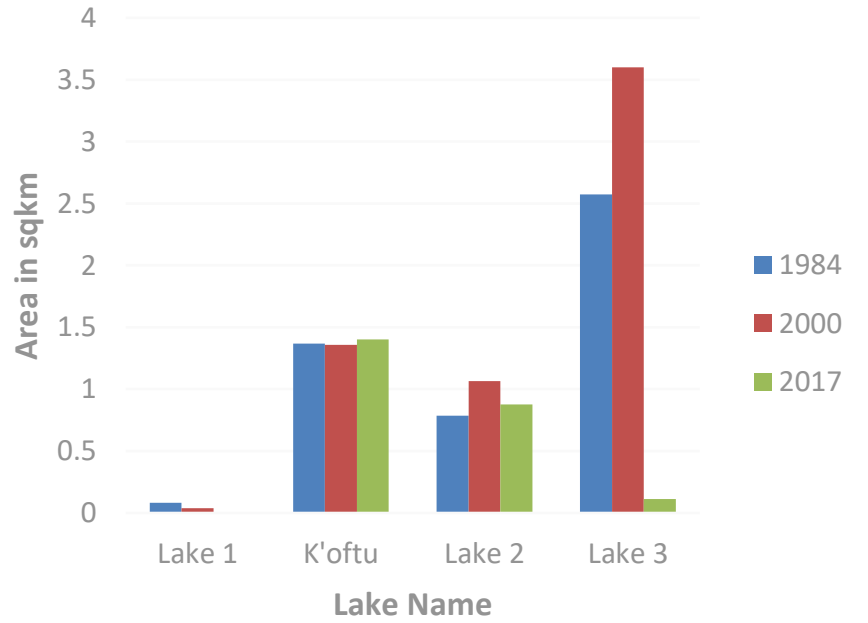

Figure 11. Area of surface water during 1984-2017

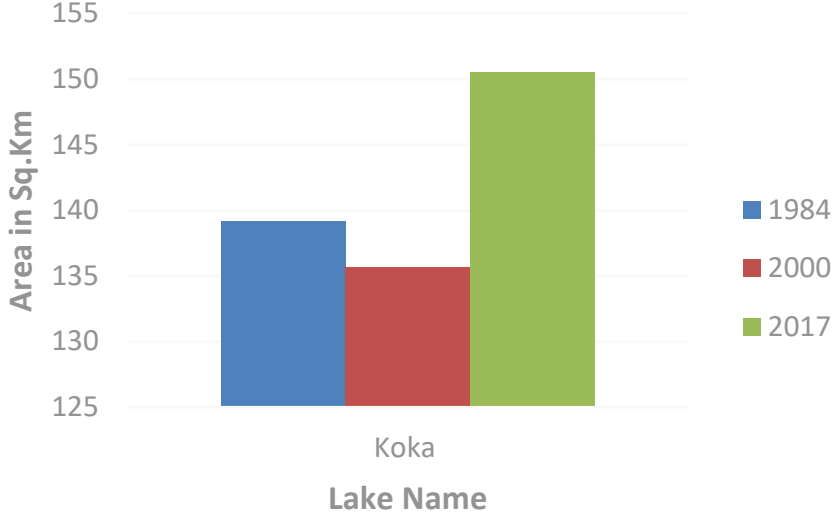

Figure 12. Area of surface water during 1984-2017

\section{$1984-2000$}

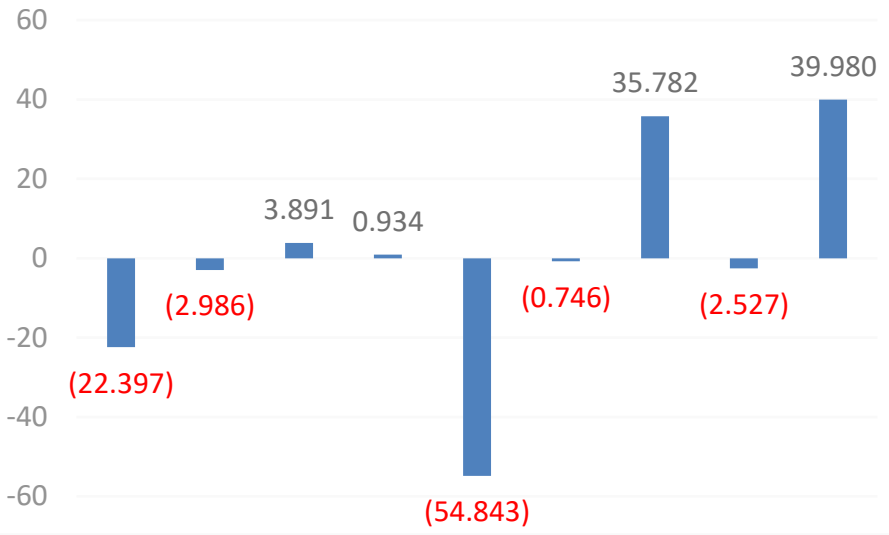

Figure 13. Area of surface water in percentage during (19842000).

\section{0-2017}

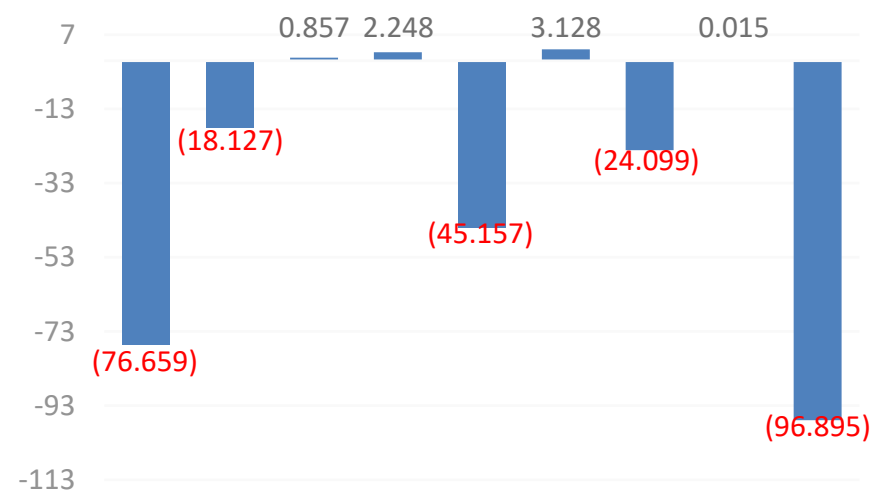

Figure 14. Area of surface water in percentage during (20002017) 


\section{CONCLUSION}

This study aimed to model the spatio-temporal changes of Lakes in Adama woreda and its surrounding in the period 1984-2017. Through a comparative analysis, the NDWI was selected and employed for this purpose.

The results showed an intense decreasing trend in the lakes of chelekleka, kiroftu, lake 1 and lake 3 of surface area in the period 1984-2017, especially between 2000 and 2017 when the lake lost about $1.309 \mathrm{~km} 2$ (one third) of its surface area compared to the year 2000 , which is equivalent to $76 \%, 18 \%$ , $0.03 \%$ and $96 \%$. Interestingly koka lake has shown very erratic changes in its area coverage by losing almost 3.5 sq.km between 1984 and 2000 and then climbing back up by 14.8 sq.km in 2017. Percentage of increment was observed that $10.6 \%$ as compared with previous year. This, makes Lakes in Adama woreda and its surrounding with a very dramatic decline and rise history in about thirty-three years' period. If such a decreasing trend in Lakes in Adama woreda continues, it is very likely that the lake will lose its entire water surface in the near future

\section{REFERENCES}

Salmon, B.P., Kleynhans, W.,van Den Bergh, F., Olivier, J.C., Grobler, T.L,; Wessels, K.J., 2013. Land cover change detection using the internal covariance matrix of the extended Kalman filter over multiple spectral bands, IEEE J. Sel. Topics Appl. Earth Observations Remote Sens, Vol. VI, pp. 1079-1085.

Demir, B., Bovolo, F., Bruzzone, L, 2013.Updating land-cover maps by classification of image time series: A novel changedetection-driven transfer learning approach,IEEE Trans. Geosci. Remote Sens, Vol.51, pp. 300-312.

Volpi, M., Petropoulos, G.P., Kanevski, M, 2013. Flooding extent cartography with Landsat TM imagery and regularized Kernel Fisher's discriminant analysis,Comput. Geosci ,Vol.57,pp. 24-31.

Brisco, B., Schmitt, A., Murnaghan, K., Kaya, S., Roth, A,2013.Sar polarimetric change detection for flooded vegetation,. Int. J. Digit. Earth, Vol. VI, pp. 103-114.

Kaliraj, S., Muthu Meenakshi, S., Malar, V.K,2012.Application of remote sensing in detection of forest cover changes using geostatistical change detection matrices-A case study of devanampatti reserve forest, tamilnadu, India,Nat. Environ. Polluti. Technol,Vol. XI, pp. 261-269.

Markogianni, V., Dimitriou, E., Kalivas, D.P,2013.Land-use and vegetation change detection in plastira artificial lake catchment (Greece) by using remote-sensing and GIS techniques, Int. J. Remote Sens, Vol. XXXIV, pp. 1265-1281.

Bagan, H., Yamagata, Y.,2012.. Landsat analysis of urban growth: How Tokyo became the world's largest megacity during the last 40 years,. Remote Sens. Environ, Vol. CXXVII, pp. 210222.

Raja, R.A.A., Anand, V., Kumar, A.S., Maithani, S., Kumar, V.A.,2013. Wavelet based post classification change detection technique for urban growth monitoring, J. Indian Soc. Remote Sens, Vol. XLI, pp. 35-43.
Dronova, I., Gong, P., Wang, L,2011.Object-based analysis and change detection of major wetland cover types and their classification uncertainty during the low water period at Poyang Lake, China,Remote Sens. Environ, Vol. CXV, pp.3220-3236.

Zhu, X., Cao, J., Dai, Y,2011.A Decision Tree Model For Meteorological Disasters Grade Evaluation of Flood,In Proceedings of 4th International Joint Conference on Computational Sciences and Optimization 2011, Kunming and Lijiang, Yunnan, China, 15-19,pp. 916-919.

Ridd, M.K., Liu, J,1998.A comparison of four algorithms for change detection in an urban environment,Remote Sens. Environ, Vol. LXIII, pp.95-100.

Lu, S., Wu, B., Yan, N., Wang, H,2011.Water body mapping method with HJ-1A/B satellite imagery, Int. J. Appl. Earth Obs. Geoinf, Vol.XIII, pp.428-434.

Desmet, P.J.J., Govers, G,1996. A GIS procedure for automatically calculating the USLE LS factor on topographically complex landscape units,J. Soil Water Conserv, Vol.LI, pp.427433 .

Zhou, W., Wu, B,2008. Assessment of soil erosion and sediment delivery ratio using remote sensing and GIS: A case study of upstream chaobaihe river catchment, north China, Int. J. Sediment Res,Vol.XXII, pp.167-173.

Du, Z., Linghu, B., Ling, F., Li, W., Tian, W., Wang, H., Gui, Y., Sun, B., Zhang, X,2012.Estimating surface water area changes using time-series Landsat data in the qingjiang river basin,China.J.Appl.RemoteSens, Vol.VI,doi:10.1117/1.JRS.6.06 3609

Sun, F., Sun, W., Chen, J.,Gong, P,2012.Comparison and improvement of methods for identifying waterbodies in remotely sensed imagery, Int. J. Remote Sens, Vol.XXXIII, pp.6854-6875.

Water Body Extraction from Multi-Source Satellite Images. Available online: http://citeseerx.ist.psu.edu/viewdoc/download?doi=10.1.1.301.8 $.33 \&$ rep=rep1\&type $=$ pdf (accessed on 21 June 2003).

$\mathrm{Xu}, \mathrm{H}, 2006$. Modification of normalised difference water index (NDWI) to enhance open water features in remotely sensed imagery,Int. J. Remote Sens, Vol.XXVII, pp.3025-3033.

Water Body Extraction And Change Detection Based on MultiTemporal SAR Images. Available online: http://adsabs.harvard.edu/abs/2009SPIE.7498E..96Z (accessed on 21 January 2014).

Zhou, H., Hong, J., Huang, Q,2011.Landscape and water quality change detection in urban wetland: A post-classification comparison method with IKONOS data,Procedia Environ. Sci,Vol.X, pp.1726-1731.

Tang, Z., Ou, W., Dai, Y., Xin, Y,2013. Extraction of water body based on Landsat TM5 imagery-A case study in the Yangtze river, Adv. Inf. Comm. Technoly, Vol.CCCXCIII, pp.416-420.

Li, W., Du, Z., Ling, F., Zhou, D., Wang, H., Gui, Y., Sun, B., Zhang, X,2013.A comparison of land surface water mapping using the normalized difference water index from TM, ETM+ and ALI,Remote Sens, Vol.V, pp.5530-5549. 
McFeeters, S.K,2013. Using the normalized difference water index (NDWI) within a geographic information system to detect swimming pools for mosquito abatement: A practical approach,Remote Sens, Vol.V, pp.3544-3561.

Moradi.M ,Sahebi.M , Shokri.M,2017.Modified Optimization Water Index (Mowi) For Landsat-8 Oli/Tirs,The International Archives of the Photogrammetry, Remote Sensing and Spatial Information Sciences, Volume XLII-4/W4, 2017 Tehran's Joint ISPRS Conferences of GI Research, SMPR and EOEC 2017, 7 10 October 2017, Tehran, Iran.

McFeeters, S. K,1996. The use of the Normalized Difference Water Index (NDWI) in the delineation of open water features,International journal of remote sensing,Vol.XVII, pp.1425-1432.

$\mathrm{Xu}, \mathrm{H}, 2006$.Modification of normalised difference water index (NDWI) to enhance open water features in remotely sensed imagery,International journal of remote sensing, Vol.XXVII, pp.3025-3033.

Irons, J. R., J. L. Dwyer ,J. A. Barsi,2012.The next Landsat satellite: The Landsat data continuity mission, Remote Sensing of Environment, Vol.CXXII, pp.11-21.

Tulbure, M. G, M. Broich, 2013. Spatiotemporal dynamic of surface water bodies using Landsat time-series data from 1999 to 2011,.ISPRS Journal of Photogrammetry and Remote Sensing, Vol.LXXIX, pp.44-52.

Ko, B. C., H. H. Kim,J. Y. Nam,2015.Classification of potential water bodies using Landsat 8 OLI and a combination of two boosted random forest classifiers,Sensors, Vol.XV, pp.1376313777.

Sethre, P. R., B. C. Rundquist, P. E. Todhunter,2005.Remote detection of prairie pothole ponds in the Devils Lake Basin, North Dakota,GIScience \& Remote Sensing, Vol.XLII, pp.277296

Klein, I., A. J. Dietz, U. Gessner, A. Galayeva, A. Myrzakhmetov .,C. Kuenzer,2014.Evaluation of seasonal water body extents in Central Asia over the past 27 years derived from mediumresolution remote sensing data,International Journal of Applied Earth Observation and Geoinformation, Vol.XXVI, pp.335-349.

Ji, L., L. Zhang., B. Wylie,2009.Analysis of dynamic thresholds for the normalized difference water index, Photogrammetric Engineering \& Remote Sensing, Vol.LXXV, pp.1307-1317.

Du, Z., Linghu, B,. Ling, F., Li, W., Tian, W., Wang, H., Gui, Y., Sun, B., Zhang, X,2012.Estimating surface water area changes using time-series Landsat data in the qingjiang river basin, China. J. Appl. Remote Sens, doi:10.1117/1.JRS.6.063609.

McFeeters, S.K,1996.The use of the normalized difference water index (NDWI) in the delineation of open water features,. Int. J. Remote Sens, Vol.XVII, pp.1425-1432.

Li, W., Z. Du, F. Ling, D. Zhou, H. Wang, Y. Gui, B. Sun., X.Zhang,2013.A comparison of land surface water mappingusing the normalized difference water index from TM, ETM+and ALI,Remote Sensing, Vol.V, pp.5530-5549.

Shen, L and C. Li,2010.Water body extraction from Landsat ETM+ imagery using adaboost algorithm,Geoinformatics, 2010 18th International Conference on, IEEE.
Komeil Rokni., Anuar Ahmad ., Ali Selamat., Sharifeh Hazini,2014.Water Feature Extraction and Change Detection Using Multi temporal Landsat Imagery,Remote Sens, Vol.VI, pp.4173-4189, doi:10.3390/rs6054173.

Shen L., Li C,2010.Water Body Extraction from Landsat ETM+ Imagery using Adaboost algorithm,Proceedings of 18th International Conference on Geoinformatics, Beijing, China,pp. $1-4$.

Fang-fang Z., Bing Z., Jun-sheng L., Qian, S., Yuan-feng W., Yang S.,2011.Comparative analysis of automatic water identification method based on multispectral Remote Sensing,Procedia Environmental Sciences, Vol.XI, pp.14821487.

Jensen, J.R.,2004.Introductory digital image processing: A remote sensing perspective, 3rd edition (NJ: Prentice Hall Logicon Geodynamics, Inc).

Yanan Wang ., Fang Huang., Yuchun Wei.,2013.Water Body Extraction from LANDSAT ETM+ Image Using MNDWI and K-T Transformation, 21st International Conference on Geoinformatics (GEOINFORMATICS), Issue Date: 20-22 June 2013.

Vivek Kumar Gautama, Piyush Kumar Gaurava , P Murugana, M Annadurai.,Assessment of Surface Water Dynamicsin Bangalore using WRI, NDWI, MNDWI,Supervised Classification and K-T Transformation.International Conference On Water Resources, Coastal And Ocean Engineering (Icwrcoe 2015). 